Received: $17-09-2021$

Accepted: 19-11-2021

Published: 27-12-2021

\title{
CHINA'S WOLF WARRIOR DIPLOMACY ON SOCIAL MEDIA IN THE ERA OF
} COVID-19

Wiwiek Rukmi Dwi Astuti

Universitas Pembangunan Nasional Veteran Jakarta

Raden Maisa Yudono

Universitas Pembangunan Nasional Veteran Jakarta

Garcia Krisnando Nathanael

Universitas Pembangunan Nasional Veteran Jakarta

Email: wiwiek.rukmi@upnvj.ac.id

\begin{abstract}
Diplomacy is significantly influenced by development of technology and communication. The role of diplomats as frepresentatives of the country has been redefined along with public communication activities increasement through social media. This study provides an overview of China's efforts in influencing the formation of public images and opinions through social media carried out by its diplomats. Their aim is to defend China's handling of the COVID-19 pandemic. This study uses qualitative methods, providing in-depth descriptions through data collection techniques based on internet-based research. This study shows that China is trying to demonstrate hard-line diplomacy called wolf warrior diplomacy. Through social media, Chinese diplomats are seen as government agents who promote national interests of their country, which in this context is related to the COVID-19 pandemic. China's courage in taking an unconventional approach to the concepts and practices of traditional diplomacy and international communication is seen as part of China's long-term plan.
\end{abstract}

Keywords: China, COVID-19, Diplomacy, Social Media, Wolf Warrior

\begin{abstract}
Abstrak
Dinamika diplomasi dipengaruhi secara signifikan oleh kemajuan teknologi dan komunikasi. Peran diplomat sebagai representatif negara mengalami redefinisi yang menyesuaikan dengan peningkatan aktivitas komunikasi publik melalui media sosial. Penelitian ini memberikan gambaran mengenai upaya Tiongkok dalam mempengaruhi pembentukan citra dan opini publik melalui media sosial yang dilakukan oleh para diplomatnya. Tujuan mereka adalah untuk membela penanganan Tiongkok terhadap pandemi COVID-19. Penelitian ini menggunakan metode kualitatif, memberikan deskripsi yang mendalam melalui teknik pengumpulan data berbasis internet. Hasil penelitian ini menunjukkan Tiongkok berupaya untuk menunjukkan diplomasi garis keras yang disebut dengan diplomasi prajurit serigala. Melalui media sosial, para diplomat Tiongkok dilihat sebagai agen pemerintah yang bertugas untuk mempromosikan kepentingan nasional negaranya, yang dalam konteks ini adalah terkait pandemi COVID-19. Keberanian Tiongkok dalam mengambil pendekatan yang tidak lazim dilakukan dalam konsep dan praktik diplomasi tradisional dan komunikasi internasional dilihat sebagai bagian dari rencana jangka panjang Tiongkok.
\end{abstract}

Kata kunci: COVID-19, Diplomasi, Media Sosial, Prajurit Serigala; Tiongkok 


\section{Introduction}

China released a short animation titled "Once Upon a Virus" which satirized the United States' response to China's discovery of the coronavirus in April 2020. The video uses Lego-like figures, namely the shape of a terracotta warrior representing China, and the shape of the Statue of Liberty to represent the United States. In the video which is less than 2 minutes long, it is described how China is actively informing things related to COVID-19, but the United States has consistently refused and ignored the information. As of December 2020, the video has been watched on the New China TV YouTube channel by more than 2.2 million people. The distribution of the video was also carried out through social media, Twitter, and it is interesting that the official Twitter account of the Chinese Embassy in Paris also posted it. In addition, a number of Chinese diplomats also continued to disseminate the video on their Twitter accounts.

Participation of diplomats in disseminating this provocative video invites us to review the definition of diplomacy and the function of diplomats. Diplomacy can be understood as the art of representing the national interests of a country, through the use of peaceful means. The art is applied as a tactic in managing formal relations between governments of sovereign/independent countries. However, along with advances in technology and communication, it will automatically affect the practice of international communication and diplomacy. The emergence of the internet and the widespread use of social media, have made them a communication tool that allows exchange, publication, and storage of information. China is one of many countries that have started to use social media as a means of communication to the international community.

Regarding to COVID-19 pandemic, China is the country where the virus was discovered, and resulted in a high death rate in the country, especially in Wuhan City, the capital of Hubei Province. The virus was discovered at the end of 2019, until finally in March 2020 it was declared a global pandemic. Many eyes are on China, because they considered that China is the one who started this pandemic. These view is also caused by the incessant attacks from US politicians, especially former President Donald Trump, who accused China of this disaster, both in terms of disinformation such as deliberately covering up facts, failing to stem the spread of the virus to other countries, even as the party who deliberately created this virus. The naming of COVID-19 was even given the term "Chinese virus" or "China virus" so that it 
became a stigma in the international community.

Facing this reality, China does not remain silent, but responds by showing aggressiveness to its diplomats and the power of a very nationalist media to change the negative image inherent in the country. Martha (2017) said that China actively uses the media for foreign interests and its country's public diplomacy. China shows its country's soft power by recognizing the role of television as forming a positive image, especially after the era of transformation in China. Through the media, China wants a change in the image that is well received by the international community, that it is a developed, prosperous, and peaceful country.

This paper understands that the media acts as an agenda setting that upholds China's national interests. China's main media office, Xinhua/New China TV, under the direct control of the Chinese Communist Party's (CCP), Propaganda Department, was the first to launch the "Once Upon a Virus" video. In fact, there is also a follow-up video, which was uploaded in early June 2020, entitled "Once Upon a Virus 2". The video illustrates the United States Central Intelligence Agency providing training to lie about the origins of COVID-19. The two videos depict China's retaliatory attack on the United States, which is fighting to create a global narrative regarding COVID-19. From the New China TV YouTube channel, the propaganda was then forwarded through social media, Twitter, by a number of Chinese media accounts and Chinese diplomats. BBC (2019) describes that in 2019, Chinese ministries and senior diplomats began logging into Twitter in their official capacity and tweeting in a somewhat undiplomatic tone. $\mathrm{BBC}$ has identified 55 Twitter accounts run by Chinese diplomats, embassies and consulates, 32 of which were created in 2019.

\section{Figure 1. Increasing Number of Chinese}

Official Twitter Accounts

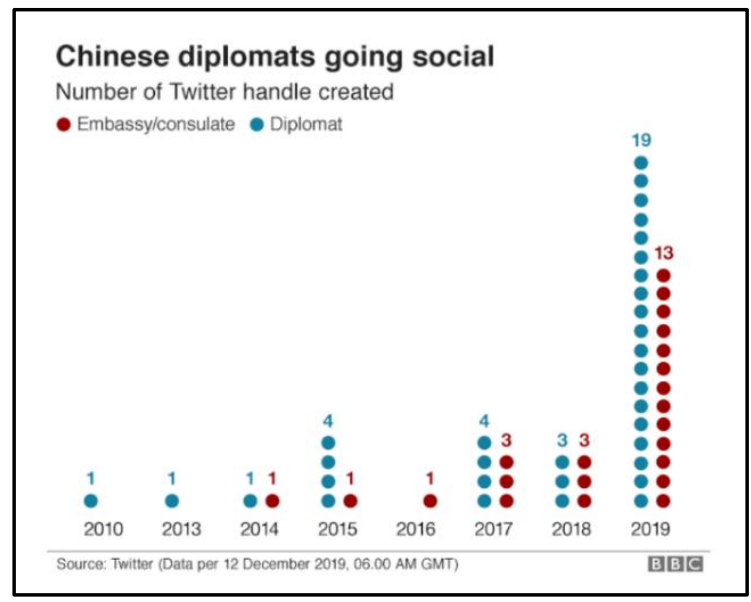

Source: BBC, 2019

Propaganda is basically a deliberate and systematic effort to use communication media to influence the public to react in accordance with what the propagandist wants (Jowett \& O'Donnell, 1994). In this context, China seems to be using Twitter to create a positive narrative for its country. One strategy is to create content using 
symbols (words, attitudes, flags, images, monuments or music) that influence other people's thoughts or actions with a view to their beliefs, values and behavior. The content is then reposted by thousands of personal Twitter accounts. New York Times (2020) reports that of the approximately 4,600 accounts that reposted tweets from Chinese official accounts and state-run media accounts over the past week, many were acting suspiciously. The fact is one in six Twitter accounts that tweet at such a high frequency, turns out to have only few followers, as if they were being used as loudspeakers, not as a sharing platform. Of course, Western media immediately saw it as a structured Chinese propaganda strategy, especially considering that Twitter itself could not be accessed from China.

The study of Chinese propaganda has a long history, in early studies on Chinese propaganda, they focused on the central role of the control system of the Chinese Communist Party (CCP) over citizens and party cadres. Shambaugh (2007) found a study conducted by Solomon, Teiwes, Schurmann, Schoenhals, Whyte, Johnson, Yu, Chang and several academics showing that propaganda and indoctrination are the strengths of the People's Republic of China (PRC). The findings of their study confirmed Mao Ze
Dong's role as a propagandist and with his government regime used various forms of propaganda to control citizens.

Based on this thought, Shambaugh argues that the individual ability of party cadres determines and the party system formed determines the success of CCP propaganda. Furthermore, Shambaugh tries to capture what is the main challenge for CCP's propaganda activities, namely the process of commercializing the media industry, he states that the commercialization that occurs puts pressure on the state and parties as well as media players. The manifestation of this pressure is the need for adjustments to the substance of propaganda carried out by the state and parties, the substance of top-down propaganda must be adjusted to the wishes of the public (bottom-up). Not only substance, Shambaurgh stated that the adjustment of Chinese propaganda also occurs to propaganda agents in the media industry, they must find a meeting point between their roles as state and party propaganda agents and still have commercial appeal to the public.

Furthermore, Hagström and Nordin (2020) review Chinese propaganda by using different view of the soft power carried out by China to the international community. They stated that soft power, which has been the basis of Chinese 
propaganda, is soft power which emphasizes the concept of harmony that has been developing in Chinese society. The concept of harmony that is believed by the Chinese government is the use of communication as an effort to build empathy and identify China as a unifying force and an effort to form a "China Dream". Hagström and Nordin focus on how the Chinese government is trying to shape a grand narrative about a more humanist China. Of course, with an understanding based on Chinese culture and traditions as an advanced nation and has different strengths from other established countries.

In relation to COVID-19 pandemic, the study of Chinese propaganda does not stop there. COVID-19 pandemic is an ideal time to see the content and form of propaganda carried out by China. Wen (2021) focuses on study about efforts made by the $\mathrm{CCP}$ in conducting "party diplomacy" throughout the world, especially in the main issue of handling the COVID-19 pandemic in China, and how China's role in handling domestic and foreign affairs. Wen stated that the CCP's "party diplomacy" activities during 2020 were increasingly aggressive in campaigning or propaganda for China's achievements in dealing with the COVID19 pandemic. Wen stated that CCP through
The International Department (IDCPC, 中 共中央對外聯絡部

Zhonggong

zhongyang duiwai lianluobu) sent messages to all partners around the world that China is a country that is able to overcome the COVID-19 pandemic, and is ready to help partner countries in overcoming this pandemic. The Chinese government and $\mathrm{CCP}$ continue to emphasize this message by using slogans such as "The China Solution" and "The Community with a shared future for mankind". Wen's study also shows that China's efforts to frame itself as the party affected by the COVID-19 pandemic and with the will to tackle the COVID-19 pandemic together are not only aimed at the international public, but also provide a direct message to the Chinese people to remain calm and trust in the their government.

Based on the explanation above, this paper aims to analyse China's efforts to influence the formation of public image and opinion through social media, especially those carried out by its diplomats during COVID-19 pandemic. The author presenting about how China's propaganda system works to provide a comprehensive picture of China's soft power. In this way, China's practice of international communication and diplomacy can be well 
understood, especially during COVID-19 pandemic.

\section{Method}

This paper provides an in-depth description of the issues by using a qualitative method. This method becomes a research tool, technique, and strategy that helps writers to collect, interpret, and analyse data, especially from the literature. According to Lamont \& Boduszynzki (2020), qualitative methods are carried out using an inductive line of thought, because qualitative researchers tend to produce theoretical propositions from empirical observations. Then, data collection technique is internet-based, that official reports and press releases of institutions or agencies are categorized as primary data. Meanwhile, news in mass media, articles, books, and scientific journals will be categorized as secondary data. In process of collecting data on the internet, researchers must be careful in checking reliable sources, because of the high circulation of content and information on the internet.

International communication, which focuses on public diplomacy and propaganda, is main concept used in this paper. International communication is understood as communication made between communicators representing a country to convey messages relating to the various interests of their country, to communicants representing other countries with the aim of obtaining wider support. In general, highlighting the state as an important actor, international communication aims to create a dynamic relationship between two or more countries. In addition, its function is also to help achieve the goals of international relations and improve the desired outcomes. Thus, international communication is closely related to the concept and practice of diplomacy.

$$
\text { In today's digital era, }
$$
communication can be occurred easily, especially with rapid spread of information. World community can find out anything through the gadgets they have. In the context of diplomacy, advances in information technology and media have led to significant changes in diplomatic activity (Djelantik, 2017). This specifically also affects public diplomacy, namely government activities that aim to create a positive image of their country in other countries. Public diplomacy is different from traditional diplomacy, which focuses on government-to-government relations, namely by targeting non-governmental publics in achieving their activities. Public diplomacy designed by the government, with the flow of information being topdown, and focusing on strategy and mass 
communication (d'Hooghe, 2015). This concept is used in this paper, especially regarding China's diplomacy. d'Hooghe added that individuals are positioned as targets and instruments of foreign policy, so efforts are needed to be carried out effectively.

Public diplomacy is closely related to the concept of soft power. Nye (2008) mentions soft power is the ability to influence others to get desired results through attraction rather than coercion or amercement. Nye explained that public diplomacy is an important tool in the use of smart power, so it is important for state to understand the role of credibility, selfcriticism, and civil society. Public diplomacy aims to attract the attention of the international community through the exploration of the country's potential resources, particularly through broadcasting, cultural exports, and various other exchanges. However, Nye argues that if the cultural content, values, and policies of a country are not attractive, then the public diplomacy is merely broadcasting, but not becoming an instrument for achieving soft power. Sometimes, if the state is too arrogant in showing off its state policies, then public acceptance may think that it is just propaganda, which does not produce positive attraction to the country.
Furthermore, the country's soft power relies on its cultural resources, values, and policies, so a smart strategy is needed to combine soft power and hard power resources. Cultural resources are places and characteristics of the country that appeal others; political values are when the concepts and practices are in line with what the public believes, at home and abroad; and foreign policy is when the country looks legitimate and has moral authority (Nye, 2008). The enforcement of public diplomacy cannot be separated from communicating foreign policy to the international community. Public diplomacy is characterized by the involvement of all stakeholders in the process (Hennida, 2010). It is stated that the stakeholders are starting from the Ministry of Foreign Affairs and other ministries that run the government, private sector, NGOs, media, and individuals. With such a diverse portion of involvement, it is necessary to design a good communication strategy. So, the strategy in public diplomacy must pay attention to all stages, starting from informing, involving, and influencing which is built at the domestic and international levels.

Hennida states that public diplomacy revolves around process of dialogue and debate, which includes sensitive and controversial themes. 
Therefore, the author also puts forward the concept of propaganda as an analytical tool in this paper. According to Jowett \& O'Donnell (1994), propaganda has been studied as history, journalism, political science, sociology, and psychology, as well as from an interdisciplinary perspective. The use of propaganda that emphasizes goals, is associated with control and is considered a deliberate attempt to change or maintain the balance of power in favour of the propagandist. Deliberate effort is linked to clear ideological and institutional goals. In fact, the purpose of propaganda is to transmit ideology to an audience with a related purpose. To quote Taithe $\&$ Thorton (Jowett \& O'Donnell, 1994), the purpose of propaganda is to convince, win and change. Therefore, propaganda must be convincing, enforceable and honest within its own authority. The formation of the term propaganda is also an indication of the way in which political entities judge the way political messages are communicated, as propaganda promotes ways and defines them.

In the literature on propaganda, practices dominated by the United States have emerged. For example, Jowett \& O'Donnell illustrates that during the Cold War era, the international community listened to Voice of America (VOA) broadcasts and found satisfaction with their thirst for information, and thus seemed to have altruistic motives. However, the information they receive from VOA is injected ideologically to shape positive perceptions of the United States and its allies, as well as to manipulate attitudes toward democracy, capitalism, and freedom. For most Americans, this was not considered a negative practice, but communist government officials reacted and viewed it negatively. The popularity of VOA is an example of apparently altruistic communication designed to facilitate the acceptance of an ideology.

Propaganda through mass media has become a common thing in the constellation of international relations. In addition to the mass media, the film industry is also a vehicle for state propaganda. The most well-known is, of course, Hollywood, which has always imaged the United States as a developed, rich, and strong country both economically and militarily. After the 9/11 tragedy, the United States with the slogan 'war on terror' was also implanted through its films. The plot of the story about the patriotism of the United States army against terrorists depicted by the majority of the Middle East is an example. If we look at the Chinese movie industry, it can be said that China has also directed its movie industry as Hollywood has. Lutfi (2019) describes 
through movie Wolf Warrior II, China conveys its propaganda to its people and also to the world that China has existence and dominance in the fields of military, security, and defence. Not only that, China also wants to show its strategic position in the context of its political and economic relations with Africa, so as to shift the role and dominance of the United States in Africa.

The emergence of the internet and social media known as new media has encouraged countries to participate in using them to spread propaganda in international communication and public diplomacy. As in the movie Wolf Warrior II, there is a scene of an American citizen asking his government for help via Twitter and telephone but not getting a good response. This can be seen as a form of satire against the US, especially Donald Trump, who is known to be very fond of social media and has created many controversial tweets. The interesting fact is that the media coverage generated from Donald Trump's tweets is very significant, both in national and international news. Therefore, social media as a means of communication by the state government, starting from the President, Prime Minister, to diplomats is an issue that needs to be specifically highlighted in the scientific development of international communication.

\section{Chinese Propaganda System}

Chinese propaganda system has a long history of practice, which can be traced back to the reign of Mao Ze Dong. Structural changes often occur in accordance with the internal political interests of the CCP as well as changes in the domestic and international sociopolitical situation. Chinese propaganda is also an embodiment of China's soft power which according to the study of Hagström dan Nordin (2020) has a different essence from the soft power conception understood by the main countries. It is stated that by understanding concept of harmony, we realizing China's soft power. China is trying to show and tell big narrative that China is a great and powerful country, that has empathy and ability to unite its country without any negative actions.

The framing of China as an empathetic and unifying force is increasingly shown during the COVID-19 pandemic, that all of state organs and parties are active in communicating with all partners around the world. The grand narrative emphasizing harmony, empathy and unification is China's main narrative in removing all narratives that corner China as the party to blame in the COVID-19 pandemic.

Regarding the working system of Chinese propaganda, not much is known, 
but Shambaugh provides a description of how the Chinese propaganda system works. China's propaganda system aims to spread state ideology and propaganda as well as become a liaison between the state and citizens (the public). It is focused on internal propaganda, that is into government and domestic institutions, and also externally, namely international institutions and the international public. Shambaugh stated that the scope of this system includes print media (newspapers, magazines and publishing), electronic media (television, radio, social media), educational institutions, culture, museums, and exhibition centers.

In his research, Shambaugh finds that Chinese propaganda system had five institutions that had the authority and responsibility for disseminating Chinese propaganda. The first is Central Publicity Department (Zhong Xuan $\mathrm{Bu}$ ) or also known as CCPPD. This institution is one of five institutions that are directly under supervision of the CCP Central Committee. CCPPD has authority over the institutions of the Ministry of Culture, National News Agency, Chinese Academy of Social Sciences; People's Daily; Bureau of Broadcast, Film and Television; and New China News Agency. CCPPD also has authority up to the provincial and subprovincial (district/city) levels. The second is the Ministry of Information Industry (MII), that was formed in 1998 with the approval of the National People's Congress in March 1998. MII oversees National Radio Management Commission; State Council's Leading Group on Information Work (Guojia Xinxihua Gongzuo Lingdao Xiaozu). Main duties and responsibilities of MII are to oversight management of all forms of electronic communication throughout China which includes media companies such as radio, film and television companies. However, MII does not monitor the content of the information published by these media companies (Shambaugh, 2007).

The third agency is Xinhua News Agency, a national news agency with coverage throughout China and the world, and part of State Council. Since its establishment, Xinhua has had two roles, that is as a national information media and as a propaganda tool for the state and the party. Then, the fourth institution is The Military Propaganda System, which is an institution under the People's Liberation Army (PLA). The PLA has its own system and mechanism for disseminating state and party propaganda, the system has close ties to the CCPPD and party committees in the military. The PLA propaganda system consists of two levels, namely the first level of the General Political Department and the 
second level includes party committees, regional party branches and small party groups. The difference between the two levels lies in the party membership of the personnel (Shambaugh, 2007).

Lastly, the fifth is External Propaganda, which aimed at the foreign public that is handled by the External Propaganda Leading Group (Duiwai Xuanchuan Lingdao Xiaozu) or EPL which was formed on April 8, 1980. EPL cooperates with government institutions that initiate international cooperation with China such as Chinese People's Institute of Foreign Affairs, China Association for International Understanding, China Association for International Friendly Contact (PLA General Political Department), China Institute of International Strategic Studies (PLA General Staff Department Second Department), Shanghai Academy of Social Sciences even in EPL too involve thinktanks in their propaganda activities.

China's propaganda system does not only rely on government institutions, as discussed above, but also carried out by the CCP through the International Department (IDCPC, Zhonggong zhongyang duiwai lianluobu). The propaganda carried out by IDCPC has two public objectives, both internal and external. In the context of overcoming COVID-19 pandemic, IDCPC focuses on

establishing

close communication with its international partners. Wen (2021) writes that since March 5, 2020 IDCPC has sent 500 letters/correspondence to 120 countries and 300 parties and socio-political organizations that have good relations with the CCP. From March 2020 to January 2021, IDCPC carried out propaganda through 3 stages which was divided into "Outbreak", "Giving Back" and "New Normal" (Wen, 2021).

In the first stage, "Outbreak", IDCPC consistently provides the latest information about handling of COVID-19, especially party and government policies to partners abroad. Then in the second stage, "Giving Back", IDCPC emphasizes news and information about the achievements of the Chinese Government in overcoming the COVID-19 pandemic and encourages international solidarity and cooperation as one of the solutions to deal with COVID19. IDCPC also provides medical assistance for its overseas partners either individually or in organizations and exchanges information and experiences about handling COVID-19 in each country. Furthermore, in the third stage, "New Normal", IDCPC is more active in disseminating the importance of a new behaviour called "New Normal". Along with the "New Normal" campaign, IDCPC 
established a discussion forum specifically discussing China's cooperation with its partners. However, as if not wanting to forget another big topic, IDCPC consistently discusses the topic of Belt and Road Initiative cooperation. Two forums were formed, namely the "China-Sri Lanka Belt and Road Political Parties Joint Consultation Mechanism" and the "ChinaPhilippines Political Parties Belt and Road Consultation Mechanism, both of which were formed on 11 and 30 June 2020.

From the explanation above, the Chinese propaganda system has two major mechanisms, that is first to use all government institutions, and second to use institutions under the authority of the CCP. The weakness of this system is that there are often clashes between institutions related to authority and the public who are the objects of narrative or news.

\section{Chinese Propaganda through Wolf Warrior Diplomacy}

In cross-cultural communication studies, it is stated that most Chinese people communicate verbally indirectly. Usually, there is a deeper meaning to their words and sometimes what they mean is the very opposite of what they say. This is also a characteristic of diplomats from China. Chinese diplomats tend to be very conventional and boring. They spoke in long and roundabout way. This results in the interlocutor or listener having to read between the lines to understand the meaning. However, recently there has been a change in the diplomatic style of Chinese diplomats.

Under the $\mathrm{Xi}$ Jinping administration, most of activities of the Chinese Ministry of Foreign Affairs initially revolved around traditional diplomatic activities amid the country's growing economic weight. This then changed when Xi Jinping made changes and rejuvenation of the system, such as firing officials who were corrupt or who were unable to respond to changes in global politics along with technological developments. In The Conversation, Callick (2020) stated that the command of the People's Liberation Army was restructured to be able to project China's military power, including through its first overseas base in Djibouti, East Africa.

Improvements at the Ministry of Foreign Affairs were also carried out, especially through a significant increase in the budget from 2013-2018, which continued to increase by double digits every year (Callick, 2020). Then, the promotion of Yang Jiechi, a top diplomat, to the Politburo, the highest ranking power in China, and the establishment of the Central Foreign Affairs Commission demonstrates 
Xi Jinping's determination to make a more assertive foreign policy a national priority. From this, $\mathrm{Xi}$ Jinping showed that he has long-term plans for China's progress both in national and international capacities.

\section{Schiffbauer (2017) assesses} Chinese customs and culture as collectivism, that is practice or principle of giving priority to groups over individuals; long-term orientation that is designed in long-term planning; and restraint, which is very focused on work, even illustrating that Chinese people are live to work. Under $\mathrm{CCP}$, these customs and cultures continued to be institutionalized, creating a deep sense of nationalism.

The nationalism and fighting spirit of Chinese diplomats began to be shown aggressively since China experienced several global challenges. One of them is in the face of a trade war with the US, which results in high trade barriers for commodities from China to enter US territory. The trade war cannot be said to be one-sided, because China immediately responded by retaliating against the US. This event caused the impact and concern of other countries that are also economic partners of the two conflicting countries. Thus, both the United States and China are equally aggressive in playing their soft power, especially through media coverage, including social media.
In December 2019, the Chinese Ministry of Foreign Affairs officially launched a Twitter account, namely @MFA_China. In less than 24 hours, the account already had almost 10,000 followers. Since then, this account has been actively reporting on impartial but convincing ways, especially regarding the trade war with the United States, the case of the Uighurs in Xinjiang, and the massive demonstrations that took place in Hong Kong. Furthermore, as explained in introduction, since 2019, the increase in Twitter creation by Chinese officials and diplomats has increased dramatically. Six months since the inauguration of @MFA_China, China's ambassadors to Austria, Iran, Maldives, Mali, Namibia, Nepal, Saudi Arabia, South Africa, Suriname, United States and United Kingdom have also joined Twitter. Twitter responded to this by saying that the government's official voice on Twitter is an important element of the service it offers (Reuters, 2019).

Through the above trends, we must admit that China sees the importance of progress in mastering international communication. It does not only involve conventional media such as television and newspapers, but also takes advantage of the presence of the internet and new media. The presence of social media, which contains 
various forms of news and information, can influence the political situation because of its ability to lead public opinion. In this case, Twitter used by China has enabled public diplomacy and propaganda activities in the world of international relations. By knowing the flow of information which is generally controlled by the Western media, China sees this as something unfavourable (not supportive or negative), so China must find effective ways to create a positive narrative about its country.

China's priority in shaping positive narratives is evident during COVID-19 pandemic. With various accusations directed at China, it seems that the international community has a stigma against China. This resulted in incessant defence of China, represented by its diplomats, to desperately defend China. From there, the term wolf-warrior diplomat is attached to the current picture of China's diplomacy.

Wolf Warrior and Wolf Warrior II is a Chinese blockbuster action movies that highlights agents of Chinese special operations forces. These two movies have increased national pride and patriotism among Chinese viewers. The term wolfwarrior diplomacy is named after the two movies, describing attacks carried out by Chinese diplomats to defend China's national interests, often in a confrontational manner. The two main figures who frequently appear in media coverage are Hua Chunying and Zhao Lijian, the main spokesmen for China's Ministry of Foreign Affairs, and Liu Xiaoming, China's ambassador to the UK.

Both Hua Chunying, with her Twitter account@SpokespersonCHN account, and Zhao Lijian, with his Twitter account @zlj517 account, are both actively using Twitter to respond to external criticism of China's handling of COVID-19. With accusations directed at China, Zhao Lijian has publicly tweeted that US soldiers brought COVID-19 to Wuhan while competing at the 2019 Military World Games. He also added that there were reports that the origin of COVID-19 actually came from United States of America.

Figure 2. Zhao Lijian's tweet about the origins of COVID-19

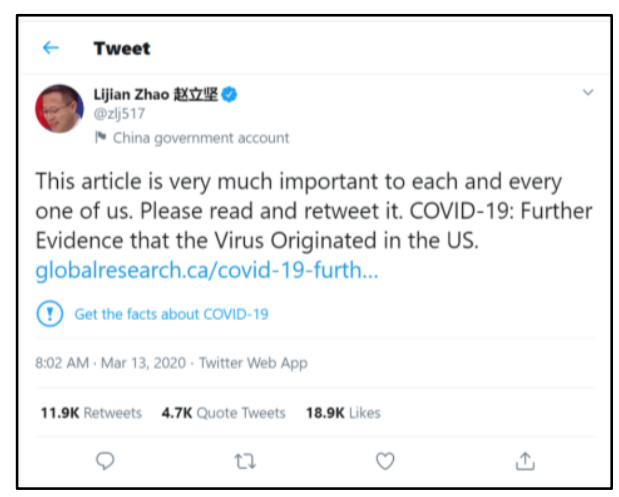

Source: Twitter, 2020

China's style of diplomacy can be seen as hard-line diplomacy that is changing the way the world views China. 
Statements and attacks were publicly conveyed by Chinese diplomats not only via Twitter, but also in other formal forums. For example, in the relationship between China and Australia, China by using its trading instruments forced Australia to conduct independent investigations in terms of research on the origins of COVID19. Through the ban on commodities from Australia such as wine and beef, Australia's position looks weak. Next, of course, what continues is an open confrontation between China and the United States. Figure 5 shows how Chinese diplomats at the UN stated that the United States was a leader for human rights violators. The United States is considered to have failed to protect its population, resulting in massive losses and impacts on the country.

Figure 3. Tweets of Chinese diplomats at the United Nations attacking the US

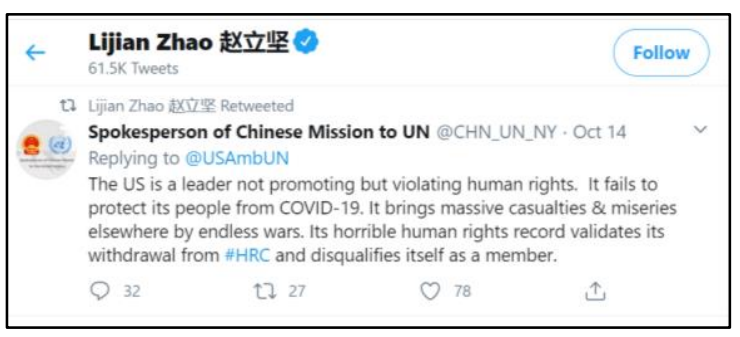

Source: Twitter, 2020

Hua Chunying, who is the director of the Information Department of the Chinese Ministry of Foreign Affairs, is very active in informing the development of China's diplomacy. For example, regarding the bilateral relations between China and countries in Africa, it is wrapped by emphasizing that China is a partner country that has contributed to the development of African countries. In addition, Hua Chunying also always shows her courage in open confrontations via Twitter to external parties. Figure 6 shows that Hua Chunying's tweet stating that the United States is the coercive master. This means that the United States in its foreign policy tends to impose, which often uses sanctions as a means of coercion. This was expressed by China, which has always been cornered by a number of countries, which was done openly as well. Thus, China continues to develop strategies in its international communications, one of which is through propaganda.

Figure 4. Hua Chunying's tweet hit back at the United States' accusations against China

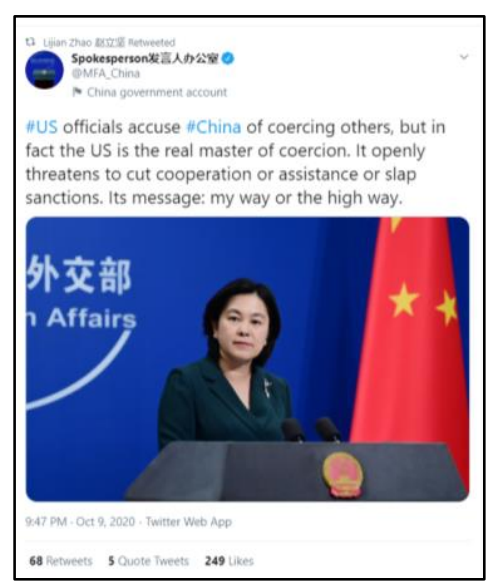

Source: Twitter, 2020

China's mastery of propaganda is actually nothing new. Under the leadership of the Chinese Communist Party, there was 
the Propaganda Department, which is currently renamed the Publicity Department. The name change is said to mark a shift in China's attention to public diplomacy. After the Cold War, China's foreign policy wanted the image of a peaceful development country (Kurlantzick, 2007). Thus, China wants the world not to see China as a threat to other countries. China imaged itself as a friendly developing country, which was starting to rise economically. But later, this changed as China's political position rose in the international relations arena.

Alden dan Chan (2021) argue that there are three reasons why China uses Twitter for diplomacy. The first reason is that Twitter has a very wide audience reach, which allows China to reach international community very quickly. With a 280character limif by Twitter, China streamlined its straightforward messages. Second, Twitter supports China to unify and measure public sentiment and international public opinion. Third, it is possible that Chinese policymakers know how much impact Twitter can have. So, with these three reasons, the use of Twitter in carrying out international propaganda, which is also wrapped in the format of public diplomacy, has become a mainstay tool for China.

Huang (2019) is also talked about
China's communications network on Twitter, which suggests that China's public diplomacy is influenced by $\mathrm{CCP}$ propaganda and censorship. Although Chinese diplomats have interacted with various types of stakeholders online (for example, domestic and foreign), the information distributed by Chinese media is the main source of content, because these media are the mouthpiece of the Chinese government, which certainly reflects the ideas of the CCC and the Chinese government.

Regarding COVID-19, China vehemently denies that its country is responsible for the outbreak of the virus so that it becomes a global pandemic. The videos titled "Once Upon a Virus" and “Once Upon a Virus 2" were first shown on New China TV's YouTube. Figure 7 shows that the video was tweeted by the official account of the Chinese Embassy in France.

This strategy implemented by Chinese diplomats can be called the virtual diplomacy method. Djelantik (2017) mentions that this method is closely related to personal diplomacy style, which is a term for state leaders who make their own approaches with parties outside the country to strengthen relations between countries. 
Figure 5. Tweet of the Chinese Embassy

\section{for France}

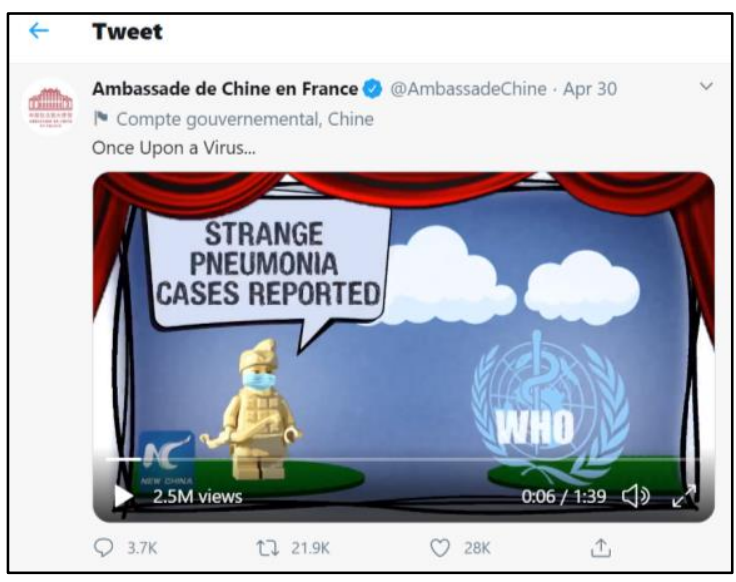

Source: Twitter, 2020

Shapiro and Rakov (2020) argue that the development of the COVID-19 pandemic presents new obstacles in carrying out diplomatic activities. Every embassy office has to get used to doing all activities online (Shapiro \& Rakov, 2020, as cited in Anshori, 2020). However, the difference in this context is that those who carry out personal diplomacy in China are state officials and diplomats. The art of diplomacy that these wolf soldiers apply shows critical thinking and great mastery of the conditions of the country they represent. And, in the art of diplomacy, there is almost no prohibition on whether it is permissible or not for diplomats to lie or commit fraud as long as it is done to fight for the national interests of the sending country (Djelantik, 2017).

China's great attention to its country's diplomatic practices shows that China has long-term planning. This creates a sense of insecurity for countries in the world. The question arises whether there will be a new imperialism centered on China? With complete mastery of hard power and soft power, China has become a particular threat to Western superpowers, namely the United States and European countries. The Chinese Foreign Ministry quoted Mao Zedong's slogan, "We will not attack unless we are attacked. But if we are attacked, we will definitely counterattack (Callick, 2020)." Therefore, although economically it will result in losses, but for now, China puts politics above all else.

\section{Conclusions}

China's propaganda system does not only rely on government institutions, but is also centered on the $\mathrm{CCP}$ as the center of Chinese propaganda. China's courage in taking an unconventional approach to the concepts and practices of traditional diplomacy and international communication is seen as part of China's long-term plan. The actions of Chinese diplomats who are aggressive and are not afraid to openly criticize other countries are considered to cause losses for China itself, especially in the economic field. However, in terms of power politics, this can position China as a country that has power and interests that can change the world political 
constellation.

When the world feels threatened by China's aggressiveness with its economies of scale, the world is trying to shape China's behaviour. However, it seems that China remains unmoved and continues to carry out countermeasures against the treatment it has received from the world, one of which is through anti-mainstream propaganda and public diplomacy, especially during the COVID-19 pandemic.

\section{References}

Alden, C., \& Chan, K. (2021, June). Twitter and Digital Diplomacy: China and COVID-19. LSE IDEAS, hal. 1-12.

Anshori, M. F. (2020). Diplomasi Digital Sebagai Dampak Pandemi Global Covid-19: Studi Kasus Diplomasi Indonesia Di Perserikatan BangsaBangsa (Pbb). Mandala: Jurnal Ilmu Hubungan Internasional, 100119.

\section{Callick, R. (2020, Mei 22). Behind}

China's newly aggressive diplomacy: 'wolf warriors' ready to fight back. Diambil kembali dari The Conversation: https://theconversation.com/behind -chinas-newly-aggressivediplomacy-wolf-warriors-ready-tofight-back-139028

d'Hooghe, I. (2015). China's Public Diplomacy. Leiden: Koninklijke Brill NV.
Djelantik, S. (2017). Teknologi Infomarsi dan Komunikasi: Studi Kasus Diplomasi Indonesia. Dalam S. D. (Ed.), Komunikasi Internasional dalam Era Informasi dan Perubahan Sosial di Indonesia (hal. 111-130). Bandung: Unpar Press.

Feng, Z. (2019, Desember 29). China and Twitter: The year China got louder on social media. Diambil kembali dari BBC:

https://www.bbc.com/news/worldasia-china-50832915

Hagström, L., \& Nordin, A. H. (2020). China's "Politics of Harmony" and the Quest for Soft Power in International Politics. International Studies Review, 22(3), 507-525. doi:https://doi.org/10.1093/isr/viz0 23

Hennida, C. (2010). Diplomasi Publik dalam Politik Luar Negeri. Masyarakat, Kebudayaan dan Politik, 2(1), 17-23.

Huang, Z. A., \& Wang, R. (2019). Building a Network to "Tell China Stories Well": Chinese Diplomatic Communication Strategies on Twitter. International Journal of Communication, 13, 24.

Jowett, G. S., \& O'Donnell, V. (1994). Propaganda and Persuasion: 4th Ed. London: Sage.

Kurlantzick, J. (2007). Charm Offensive: How China's Soft Power Is Transforming the World. New Haven: Yale University Press. 
Lamont, C., \& Boduszynski, M. P. (2020). Research Methods in Politics and International Relations. London: SAGE Publications Ltd.

Lutfi, M. (2019). Propaganda Tiongkok Terhadap Amerika Serikat Melalui Film (Analisis Isi Film Wolf Warrior II) [Unpublished bachelor's thesis]. Surabaya: Universitas Islam Negeri Sunan Ampel Surabaya.

Martha, J. (2017). Kekuatan Tiongkok melalui Media Televisi; Studi Kasus China Central Television di Afrika. Dalam S. Djelantik, Komunikasi Internasional dalam Era Informasi dan Perubahan Sosial di Indonesia (hal. 185-206). Bandung: Unpar Press.

Nye, J. S. (2008, March 1). Public Diplomacy and Soft Power. The ANNALS of the American Academy of Political and Social Science 616 (1), 94-109.

Reuters. (2019, December 4). China demands 'fighting spirit' from diplomats as trade war, Hong Kong protests simmer. Diambil kembali dari Reuters: https://www.reuters.com/article/uschina-diplomacyidUSKBN1Y80R8

Schiffbauer, L. (2017, Februari 8).

International Communications.

Diambil kembali dari YouTube: https://www.youtube.com/watch?v $=$ V7QIzj7RS5A\&t=591s

Shambaugh, D. (2007). China's Propaganda System: Institutions,
Processes and Efficacy. The China Journal, 57, 25-58.

Wen, Y. (2021). Branding and Legitimation: China's Party Diplomacy amid the COVID-19 Pandemic. The China Review, 21(1), 55-89.

Zhong, R., Krolik, A., Mozur, P., Bergman, R., \& Wong, E. (2020, Juni 8). Behind China's Twitter Campaign, a Murky Supporting Chorus. Diambil kembali dari The New York Times: https://www.nytimes.com/2020/06/ 08/technology/china-twitterdisinformation.html 